\title{
OPTIMALISASI MICROBLOGGING TWITTER SEBAGAI ALAT KEHUMASAN DALAM PERUSAHAAN
}

\section{OPTIMIZING MICROBLOGGING TWITTER AS A COMPANY TOOLS IN EQUIPMENT}

\author{
Kirana Dwitia Putri \\ Departemen Ilmu Komunikasi, Fakultas Ilmu Sosial dan Ilmu Politik, Universitas Indonesia \\ Salemba, Jakarta Pusat \\ email : kiranadp27@gmail.com \\ Irwansyah \\ Departemen Ilmu Komunikasi, Fakultas Ilmu Sosial dan Ilmu Politik, Universitas Indonesia \\ Salemba, Jakarta Pusat \\ email : dr.irwansyah.ma@gmail.com \\ (Diterima: 02-02-2018; Direvisi: 05-05-2018; Disetujui terbit: 06-06-2018)
}

\begin{abstract}
Abstrak
Pada setiap perusahaan yang menjalankan bisnisnya tentu memiliki fokus utama agar dapat mendistribusikan produk serta jasa kepada pengguna yaitu konsumen yang berada di tengah masyarakat. Perusahaan, harus mampu untuk membuat begitu banyak strategi guna melancarkan aksi distribusi dan peningkatan awareness pada konsumen mengenai perusahaan itu sendiri. Konsumen, yang berada di masyarakat memiliki hak untuk memahami produk atau jasa yang hadi di tengah mereka, dan tanpa halangan untuk mendapatkan informasi mengenai perusahaan tersebut. Di era masa kini, idealnya sudah tak lagi sulit untuk mendapatkan informasi apapun dengan bantuan internet. Begitu pula pada perusahaan yang idealnya telah melakukan optimalisasi penggunaan internet sebagai alat bantu kinerja. Penulis mengemukakan konsep yang dapat menyatukan perusahaan dengan konsumennya lewat divisi Hubungan Masyarakat menggunakan alat microblogging yang tersedia pada media sosial yaitu Twitter. Para praktisi Hubungan Masyarakat, kini dapat selangkah lebih maju untuk melakukan kampanye komunikasi pada konsumen yang semakin tersegmentasi berkat Twitter dan penyampaian informasi kini tidak terbatas ruang dan waktu.
\end{abstract}

Kata Kunci : Microblogging, Twitter, Media Sosial, Humas, Komunikasi

\begin{abstract}
Every companies that run the business, they always focus on distributing products and services to all of their consumers in public. Companies, must be able to create strategies to broaden distribution action and awareness about the company itself. Customers, residing in the public have the right to understand a product or service that is, and without any doubt they have to be always able to obtain information about the company. In today's era, ideally it is no longer difficult to get any information with the help of internet. Similarly, the ideal company has been optimizing the use of the Internet as a performance tool. The author of this research, put forward the concept that can bridge the company with consumers through the relationship with using microblogging available on social media that is Twitter. Public Relations practitioners, can communicate further to conduct a communication campaign on the increasingly segmented consumer, thanks to Twitter and the delivery of information is now not limited space and time.
\end{abstract}

Keywords : Microblogging, Twitter, Social Media, Public Relations, Communication

\section{PENDAHULUAN}

Divisi Hubungan Masyarakat telah diketahui pada umumnya merupakan penghubung utama antara perusahaan dengan masyarakat atau secara spesifik, konsumen. Hubungan Masyarakat harus mampu berperan untuk menjadi representasi bagi perusahaan di mata masyarakat dan mengantarkan pada 
keterikatan dengan perusahaan yang produknya telah hadir di tengah-tengah kehidupan masyarakat. Sebuah perusahaan mampu memikirkan strategi agar para pekerja Humas di korporasinya mampu memiliki kemampuan untuk menimbulkan keterikatan dan bahkan mampu menciptakan top of mind di benak konsumen. Memang seringkali ditemukan bahwa kemampuan perusahaan untuk menjadi pilihan utama pada masyarakat adalah dengan prestasinya dalam menciptakan produk-produk yang menjadi pelopor, memberikan harga murah namun dengan kualitas yang baik. Namun, kasus tersebut tidak akan teraplikasikan pada perusahaan baru atau start up, di sinilah peran Hubungan Masyarakat harus mampu menempatkan diri dalam sebuah situasi dimana perusahaan baru saja masuk ke dalam environment yang baru dan sudah terbentuk lebih awal dibanding keberadaan perusahaan.

Pada umumya, Hubungan Masyarakat identik dengan press release, press conference, kemampuan berbicara di depan umum (public speaking) serta muncul di media saat mengutarakan penyelesaian konflik. Di luar hal-hal yang wajib tersebut rata-rata perusahaan di Indonesia masih sedikit sekali yang memiliki strategi dalam blending di masyarakat melalui media sosial. Media sosial, sejatinya bukan hanya digunakan oleh para pemuda sebagai platform dalam berhubungan dengan relasinya. Media sosial, sangat patut dan pantas dijadikan penrantara bagi perusahaan yang ingin masuk perlahan dan smooth di tengah masyarakat yang rata-rata sudah terpapar dan berada pada era digitalisasi. Maka, industri tidak boleh kalah telak dengan kemajuan yang amat pesat ini, Hubungan Masyarakat harus terus membantu mengejar ketertinggalan dan menjadi pelopor dalam menunjukkan pada masyarakat bahwa perusahaannya mampu bergabung dalam dunia industri 4.0.

Media sosial dapat dipandang sebagai alternatif dari media mainstream atau konvensional, yang paling murah untuk dikonsumsi oleh masyarakat. Kini masyarakat menikmati pergerakan arus informasi yang cepat, tangible dan real time dimana media sosial sangat mendukung keterbukaan informasi tanpa perlu terlihat monoton dengan disajikan dalam sebuah lembaran surat kabar yang memuat banyak sekali paragraf penuh kalimat ataupun dengan terpaku pada berita di televisi yang disajikan kurang menarik dan satu arah. Berbagai platform dalam media sosial dapat melakukan keterbatasan yang tidak dimiliki media mainstream, yaitu kemampuannya untuk diakses dimana saja, terpersonalisasi dengan kebutuhan konsumen, serta tampilan yang tidak membosankan. Kita dapat melihat contoh Twitter yang membatasi akses untuk posting dalam per cuitan (tweet) nya hanya dalam 140 karakter. Hal ini akan mempermudah khalayak dalam menyerap informasi yang hanya mereka ingin serap saja tanpa harus susah payah memperhatikan informasi lainnya yang tidak sesuai dengan keinginan mereka, selain itu Twitter pun mampu mengajak khalayak untuk semakin sering melakukan update tweet yang berisi pendapat, perasaan atau pengalaman hanya dalam kalimat-kalimat singkat yang lebih menonjolkan makna. Pada tulisan ini penulis akan membahas pemanfaatan micro blogging yang merupakan salah satu strategi bagi manajemen kehumasan dari perusahaan untuk mendukung pengembangan revolusi industri 4.0 guna menghubungkan diri pada masyarakat atau 
konsumen yang telah menikmati manfaat komunikasi terdigitalisasi.

\section{LANDASAN TEORI}

\section{Definisi Korporat}

Menurut Joel Bakan, dalam bukunya The Corporation, definisi korporat adalah sebuah struktur unik dan tatanan otoritatif yang mengarahkan tindakan orang-orang yang ada di dalamnya. Korporasi juga merupakan institusi legal, yang keberadaan dan kapasitasnya untuk beroperasi bergantung pada hukum. Sebagai tambahan, Chami \& Fullenkamp menuturkan bahwa tata kelola perusahaan adalah sebuah proses menuntun dan mengatur aksi para karyawan yang bekerja atas nama sebuah perusahaan. Tujuan dari tata kelola perusahaan adalah untuk meyakinkan bahwa perusahaan tersebut mengejar maksimalisasi nilai saham, sehingga tata kelola yang baik akan melakukan efisiensi dan kesehatan nilai saham. Dalam kata lain, perusahaan mencoba untuk menyelesaikan banyak masalah dan urusan di dalamnya guna dapat dipandang oleh calon pembeli saham sebagai perusahaan yang sehat dan sustainable.

\section{Definisi Hubungan Masyarakat}

Sementara menurut Rezaei, Dana \& Ramadani dalam bukunya Iranian Entrepreneurship disebutkan bahwa tujuan dari sebuah perusahaan memiliki divisi Hubungan Masyarakat adalah untuk meyakinkan bahwa perusahaan meninggalkan impresi yang baik di tengah kumpulan konsumen. Definisi dari Hubungan Masyarakat adalah sebuah manajemen arus informasi secara mutual antara perusahaan dan publik. Dengan kata lain, Hubungan Masyarakat memberi informasi pada publik mengenai produk/layanan perusahaan sembari menerima feedback tentang bagaimana proses informasi ini berdampak pada publik.

Kehumasan dalam usahanya untuk menjadi lini terdepan dari perusahaan yang terjun kepada masyarakat membuatnya harus mampu untuk membuat branding perusahaan agar publik memberikan feedback positif atas image perusahaan yang pula positif juga tentunya. Kehumasan sebaiknya menguasai skills yang bertujuan untuk mempopulerkan brand guna kemajuan bisnis. Lewat jurnalisme perusahaan, seperti kemampuan menulis, video editing, blogging, vlogging, social media optimalization, dll, humas akan mampu mengantarkan awareness atas brand atau aktivitas perusahaan kepada publik bahkan individu. Tentunya dengan bantuan digitalisasi dalam setiap genggaman tangan publik sebagai konsumen atau calon konsumen. Lebih dari sekedar menulis dan merekam serta menyebarluaskan video, humas dapat melakukan jurnalisme pada perusahaan lewat aktivitas optimalisasi blog dan social media. Promosi, kritik, tanya jawab dan sebagainya dapat dilakukan menjadi sebuah aktivitas customer relation lewat platform digital ini. Menurut Felix Ale dalam penelitiannya Journalism and Corporate Communications, A Nigerian Case Study jurnalisme perusahaan dan komunikasi memainkan peran penting dalam mendorong para stakeholder dari perusahaan untuk memahami progress organisasi, operasi dan pengembangannya. Dengan mampu memanfaatkan blog serta social media seperti Twitter dan Instagram, Hubungan Masyarakat telah sangat membantu korporat untuk mendorong stakeholder memiliki ketertarikan untuk mengeksplorasi 
identitas dan aktivitas perusahaan. Dari setiap tweet yang menarik dan mengundang tawa seperti yang dilakukan oleh Wendy's USA, ataupun kesigapan menegur yang dilakukan oleh admin akun Twitter TNI AU dan Dirjen Pajak telah sedikit banyak mewakili kultur dan identitas perusahaan yang berguna pada ujungnya mendorong shareholder atau donatur serta konsumen berkerjasama dengan perusahaan tersebut.

\section{Definisi Microblogging}

Menurut Java (2007, p.1) microblogging merupakan fenomena yang relatif baru dan didefinisikan sebagai "sebuah bentuk blogging yang membuat pengguna menulis update teks (biasanya kurang dari 200 karakter) mengenai kehidupan yang berjalan dan mengirimkan pesan kepada teman atau relasi yang dikehendaki via pesan teks, instant messaging (IM), email atau web. Microblogging dapat digunakan lewat beberapa layanan di media sosial termasuk Twitter. Microblogging menyediakan alat untuk melakukan bentuk komunikasi yang dapat membuat pengguna melakukan penyebaran dan pembagian informasi tentang apa aktivitas yang sedang dilakukan, opini dan status. Mengacu dari ComScore, dalam waktu delapan bulan sejak launching, Twiiter memiliki 94.000 pengguna sejak April, 2007. Update dan post yang disebarluaskan lewat Twitter terdiri dari eksplanasi sebuah status dalam batasan 140 karakter. Topik-topik konten yang terdapat dalam Twitter bisa muncul dengan berbagai tema, bergantung pada apa yang menjadi minat dari pemilik akun, misalnya event yang sedang happening, cerita dan berita, serta ketertarikan lainnya. selain Twitter, instant messenger seperti Gtalk, Yahoo dan MSN juga memiliki fitur yang membuat pengguna dapat melakukan sharing status dengan list teman yang dimiliki.

Twitter merupakan platform media sosial. Seringkali dibandingkan dengan Facebook dan kadangkala dipertimbangkan pula di masyarakat sebagai sebuah platform networking paling terkenal. Perbandingan ini pun benar adanya karena memiliki kesamaan seperti misalnya keduanya adalah media sosial, dan sangat interaktif. Bagaimanapun juga, dua media tersebut sangat unik dilihat dari banyak cara. Model bisnisnya juga sangat berbeda, Twitter lekat dengan bentuk yang ringan dan minim pengiklan. Dibanding dengan Facebook yang menargetkan metode agar pengguna menghabiskan banyak waktu pada platform tersebut namun juga membentuk iklan yang lebih terpersonalisasi dengan kebutuhan penggunanya.

Menurut Java (et al. 2007), Twitter dapat dipertimbangkan dengan baik sebagai sebuah "microblog" yang konsisten akan pesan pendek dibanding pesan panjang. Microblog harus dibedakan dengan blog pada umumnya yang justru memuat panjang tulisan dengan sangat detail dan kadang sulit membuat orang tertarik untuk mengikuti dan memiliki perasaan terikat dengan blog dalam waktu yang lama. Cara microblog membuat bentuk dan kemasan komunikasi yang unik di media sosial memang terbilang baru. Menurut Murthy (2018), Twitter menggunakan teknologi yang dikembangkan di era internet awal yaitu permainan berdasarkan pesan teks dalam Multi User Dungeons (MUDs), Instant Messenger (IM), dan Internet Relay Chat (IRC). Pada akhirnya, memang akan sulit membedakan antara media sosial, social networking dan microblog. Sebagai 
pengingat yang singkat dan mudah, media sosial sendiri diciptakan sebagai media broadcast yang berfokus pada posting konten bagi jaringan luas yang dikirim oleh pengguna akun pada dunia luar yang dapat melihat konten-konten milik pengguna tersebut dengan bebas, walaupun begitu media sosia masih seringkali memberikan pilihan untuk mengatur privasi mengenai sejauh mana konten dapat dilihat oleh publik. Konten pun dapat beragam misalnya foto, update lokasi, unggahan lagu favorit, update aktivitas, dll. Contoh media sosial adalah Twitter, Path, Instagram. Social networking sendiri benar-benar berfokus untuk menjaring teman dan relasi serta keluarga, selain itu melakukan pemeliharaan dan pengembangan terhadap koneksi yang telah tercipta. Elemen-elemen yang dapat dimanfaatkan pada social networking terfokus pada kemudahan mencari relasi dan mengelompokkan pengguna di dalam lingkaran yang sejenis dengan daftar teman yang dimilikinya. Contoh-contoh elemen tersebut adalah menu untuk mencari dan menambah teman, menambahkan nama dan group sekolah atau pekerjaan. Contoh social networking adalah Facebook dan MySpace. Sementara microblog adalah media untuk menuliskan konten dengan batasan karakter yang singkat dan dapat ditujukan oleh seorang pengguna lain ataupun tidak. Selain itu microblog pun juga membuat pengguna dapat melihat dan menerima pesan dari seseorang yang ia ikuti, namun tidak serta-merta pengguna tersebut bisa mengirimkan pesan kepada seorang yang ia ikuti tersebut. Dan hal ini termasuk unik karena dalam dunia microblog, dibanding social networking lainnya, proses mengikuti atau berteman dengan akun lain tidaklah mutual.

\section{METODE PENELITIAN}

Penulis menggunakan metode penelitian kualitatif untuk menghasilkan sebuah tulisan konseptual yang memperdalam pemanfaatan sosial media dengan menekankan pada definisi konep microblogging, serta memasukkan contohcontoh dari berbagai perusahaan yang telah memanfaatkan sosial media terutama microblog sebagai alat dalam menyebarluaskan informasi serta alat bantu dalam melaksanakan praktik-praktik kehumasan.

\section{HASIL PENELITIAN DAN PEMBAHASAN}

\section{Korporat dan Humas di Luar Indonesia}

Humas di luar Indonesia telah berubah secara drastis dan tidak lagi terus menerus tentang menghubung-hubungkan perusahaan dengan media, mempersiapkan press conference dan lain-lain. Humas di banyak perusahaan di luar sana kini menyandang dan memiliki sibling yang bernama Humas Digital. Tentu bukan berarti mereka harus meng-hire saudaranya tersebut namun mereka telah berhasil menerapkan dan mempersatukan kemampuan Humas Digital dengan Humas analog (tradisional). Humas digital menurut Carrie Morgan, selaku penulis buku Above The Noise: Creating Trust, Value \& Reputation Online Using Digital Public Relations, Humas Digital adalah tentang menggabungkan Humas tradisional dengan pemasaran konten, media sosial dan mesin penelusuran: mengubah berita statis menjadi sebuah topik percakapan, dan bagaimana menggunakan media untuk berbicara langsung dengan target audiens Anda secara online.

Hasil-hasil utama yang didapatkan adalah berita dapat melesat lebih luas dan 
tertuju pada target audiens dengan lebih tepat seperti yang belum pernah ada sebelumnya di dalam sejarah melalui penggunaan platform digital, media sosial dan optimasi sistem penelusuran. Tak hanya itu, Humas Digital kini telah menggunakan (selain media sosial) blog untuk mengulas konten, berbagi berita dan juga menciptakan dialog. Humas tradisional, mereka berasumsi bahwa dirinya adalah penjembatan antara perusahaan untuk bersentuhan dan mendengar langsung dari audiens, konsumen, khalayak, dll. Namun apakah mereka benar-benar keluar dari kantor secara rutin untuk terjun ke lapangan secara langsung? Apakah mereka rutin mengadakan pertemuan dengan sales person di retail store yang tiap hari mendapatkan pertanyaa, saran dan bahkan kritik dari konsumen? Apakah Humas tradisional mampu secara analog mengumpulkan semua data, survey, form, berkas yang berisi tentang masukan dan kritik? Apakah Humas Tradisional rutin setiap triwulan atau setiap semester membuat kuliah umum, diskusi, event, consumer gathering, atau shareholder gathering untuk publik dan stakeholdernya? Penulis optimis, Humas Tradisional di luar sana mampu melakukan itu semua pada dasarnya dan pada teorinya. Namun pada praktiknya? Hal ini penulis ragukan karena mereka terbentur dengan banyaknya internal problem yang mestinya menjadi pokok utama untuk diselesaikan sebelum hal ini sampai ke publik. Namun dengan kemampuan blogging, kini pengguna blog dan media sosial berlomba-lomba untuk berkomunikasi dengan admin dari akun perusahaan agar mendapatkan respon atas pertanyaan atau bahkan hanya sekedar bercakap-cakap. Kembali lagi penulis memberi contoh, Wendy's merupakan salah satu praktik Humas Digital lewat media sosial yang menarik (sekaligus ekstrim) dimana mereka akan membalas respon audiens atau konsumen yang berkomunikasi dengan pihak Wendy's ketika membanding-bandingkan perusahaan tersebut dengan pesaing: McDonald's. Hal ini menjadi menarik karena Wendy's membalas dan berkomunikasi dengan audiens menggunakan kalimat sarkastik guna memberitahukan posisinya bahwa "Hey I could be better than McDonald's if you give it a try in our restaurant." Namun selama ini seluruh warga dunia telah mengalami 'ter-McDonald-isasi' yang menyebabkan pesaing akan sulit untuk mendapatkan tempat di top of mind pelanggan. Itulah mengapa, Wendy's mengambil langkah yang agak ekstrim dan komitmen dalam penggunaan media sosial. Dengan blog dan atau media social, perusahaan akan benar-benar terkoneksi dengan dunia.

Morgan Carrie memiliki rumusan yang telah Humas Digital selama ini lakukan $:$ Repurpose + Value $=$ Pemasaran Konten. Langkah untuk memasukkan pemasaran konten dengan cara mutakhir adalah mengganti konten yang telah Humas Tradisional miliki seperti siaran pers dan sebagainya menjadi konten segar yakni contohnya siaran pers dapat diubah menjadi presentasi Slideshare atau sebuah blog posting, informasi pada Pinterest, Facebook, LinkedIn, publikasi perdagangan atau saham yang relevan, artikel editorial, opini, informasi CSR dapat diterbitkan lewat website perusahaan dan masih banyak lainnya. 


\section{Digital Public Relations}

Menurut Theaker (2001, p.257), kebutuhan untuk menggunakan online media secara efektif saat ini sudah berjalan lurus dengan seluruh divisi Hubungan Masyarakat dalam seluruh sektor. Para praktisi Hubungan Masyarakat harus beradaptasi dengan hal tersebut. Dari data demografis mengenai penggunaan internet yang dikeluarkan oleh Mark Pinsent of Technology seperti yang terkutip dalam Theaker (2001, p.258), 31 persen wanita mengatakan mereka melakukan kegiatan online ketika menonton televisi, sementara persentase pria adalah 24.3\%. Di Inggris, angka tingkat akses website acara Big Brother meningkat paling tinggi setiap program sedang tayang. Seperti mengacu pada Evans et al. (2011, p.2), sementara koran dan televisi pernah didominasi sebagai media pilihan untuk arus informasi, internet kini menawarkan akses yang sama untuk semua yang tertarik dalam menyebarkan informasi, dengan akses yang sama dan aliran bebas informasi, internet mendukung demokrasi sejati tidak seperti media lain sebelumnya.

Heibert (2004) menyatakan bahwa internet memaksa perusahaan, organisasi dan administrasi pemerintahan pun agar mendekati arus informasi dengan rasa transparansi baru. Menurut Kirat (2007), "Media online adalah media yang utama untuk digunakan praktisi Hubungan Masyarakat secara efisien dan rasional untuk kehumasan yang efektif" (p.170). Kirat (2007) mengusulkan agar integrasi internet sebagai alat dalam praktik kehumasan kontemporer, digunakan agar mencapai kesuksesan. Setelah praktisi Hubungan Masyarakat memeluk kekuatan internet, hal itu akan mengubah praktisi Hubungan Masyarakat dalam melakukan pekerjaan mereka. Gregory (2004, p.245) mengungkapkan bahwa "Kemunculan internet dan komunikasi elektronik telah mengubah hubungan masyarakat seperti yang terjadi mengubah banyak bidang kehidupan organisasi dan bisnis."

Selain itu, penulis berpendapat setelah mempraktikkan penggunaan internet dan online media sebagai alat dalam hubungan perusahaan kepada masyarakat, industri atau perusahaan juga perlu dalam menjalankan assessment atau uji evaluasi mengenai seberapa berpengaruhnya praktik tersebut pada masyarakat, hal ini di kemudian harinya tentu akan membawa inovasi perubahan bagi perusahaan untuk tetap menjalankan dan mengembangkan hal-hal yang berjalan dengan baik semenjak praktik awal, dan mengurangi hal-hal yang tidak perlu dijalankan dengan manual atau konvensional lagi sehingga dapat mengurangi beban biaya perusahaan dan meningkatkan efisiensi campaign perusahaan. Selain uji evaluasi, praktisi Hubungan Masyarakat harus bekerjasama dengan pakar teknologi informasi dalam bidang internet security atau data security dan membuat standar operasional \& keamanan sebagai panduan perusahaan dalam menjalankan kinerja di dunia online, adapun para Hubungan Masyarakat yang menjalankan aksi dengan memberi banyak informasi pada publik lewat internet dan online media sebaiknya memberikan informasi general atau secara umum yang tidak mengundang ke arah penyerangan atau peretasan data, dan tidak menyimpan data rahasia atau sensitif pada jaringan internet atau dunia maya. Meskipun begitu menurut Evans et a. (2011, p. 3), para kritikus atau penyerang, memiliki forum terbuka di internet untuk menyuarakan pendapat negatif mereka dan dilindungin oleh peraturan pemerintah. Sehingga, Digital Public Relations memang lebih 
rentan untuk mengalami kritik terbuka dari masyarakat atau konsumennya karena hal ini merupakan salah satu unsur hasil pertukaran dan penyuaraan informasi yang cepat berkat internet.

\section{Twitter sebagai Masa Depan Hubungan Masyarakat}

Menurut penelitian yang dilakukan Evans et al. (2011) di Uni Emirat Arab, banyak responden yang mengaku tidak yakin dengan jalur Twitter sebagai alat optimalisasi Hubungan Masyarakat digital. Namun banyak pula yang menyetujui bahwa komunikasi singkat dan instan seperti microblogging akan tetap ada. Seorang karyawan sebuah perusahaan bernama Lynne Doll dari The Rogers Group menyatakan bahwa Twitter akan terus menjadi platform yang tetap disukai dan tetap harus dilihat, tetapi konsep penggunaan Twitter di sini adalah untuk tetap bertahan. Sementara seorang wakil presiden dari perusahaan tersebut menambahkan bahwa "Selama khalayak terus merespon, kami akan terus menggunakannya." Dan direktur dari perusahaan tersebut pun menyatakan kalimat keyakinan bahwa Twitter akan bertahan karena Twitter terus menambahkan lapisan fitur yang memberi cara kreatif untuk terhubung antara seorang individu dan perusahaan yang tergolong baru.

Perlu diakui bahwa sebuah penelitian yang sudah dilakukan tidak dapat menjadi ukuran keberhasilan bagi perusahaan lain untuk menjalankan sesuatu yang sama. Namun begitu, Indonesia merupakan pangsa pasar yang sangat penting bagi Twitter, seringkali Trending Topic yang muncul di Twitter berasal dari Indonesia. Selain itu, menurut survey-based data yang dikeluarkan oleh HootSuite bulan
Januari 2017, sebanyak 39 persen masyarakat Indonesia adalah pengguna Twitter. Hal ini tentu seharusnya menjadi target yang amat luas bagi masyarakat. Berdasarkan data yang disampaikan oleh Menteri Dalam Negeri (Mendagri) RI Tjahjo Kumolo pada bulan Januari 2016 saja, masyarakat Indonesia berjumlah 257.912.349 jiwa. Apabila secara kasar kita hitung 39 persen dari jumlah tersebut, akan mencapai jumlah 98.006.692 juta jiwa. Tentu, apabila perusahaan melakukan optimalisasi dalam pergerakan kampanye komunikasi lewat Twitter, informasi akan tersampaikan dengan baik dan akan sangat menghemat pengeluaran biaya serta meningkatkan efisiensi dengan tujuan menyampaikan informasi ke sebanyakbanyaknya target market yang sesuai dengan kateori konsumen perusahaan.

\section{Buzzer \& Social Media Activist}

Menanggapi pentingnya media sosial bagi keberlangsungan perusahaan, tentu merupakan hal yang harus segera dipelajari oleh banyak Humas dan Korporasi di Indonesia. Pelatihan, pembelajaran mendalam, teori \& praktik amat dibutuhkan. Namun tidak kita pungkiri bahwa digitalization, internet, media sosial, telah membuka kesempatan interaksi yang begitu luas yang bahkan awalnya terasa mahal dan sulit untuk dilakukan. Salah satunya adalah dengan menyandang seorang 'duta' buzzer dan social media activist yang mewakili korporasi atau perusahaan sesuai dengan visi misi dan sanggup menyuarakannya. Definisi dari new media activist sendiri menurut Leah Lievrouw dalam bukunya Alternative and Activist New Media adalah seseorang yang memodifikasi artifak komunikasi, praktik dan pengaturan sosial dari sebuah informasi baru dan teknologi 
komunikasi untuk menantang atau mengubah dominasi serta cara berperilaku dalam sosial, politik dan budaya lewat langkah-langkah yang dapat diekspektasi dan diterima.

Kata-kata 'buzzer' mungkin sedikit banyak masih asing di kalangan pengguna pasif media sosial yang datang dari generasi $\mathrm{X}$, baby boomers dan sebelumnya. Sementara banyak dari mereka yang masih menggerakkan perusahaan lewat tahtanya di level manajerial ke atas. Buzzer seharusnya sudah banyak diketahui manfaatnya dan membuang rasa malu atau gengsi dalam penggunaannya karena mungkin saja terkesan tidak berdikari, tidak memanfaatkan kemampuan internal dan sampai harus menggunakan jasa kemampuan seseorang yang telah tersohor skillnya dalam social media activism. Harus banyak meneliti dan menelaah ke perusahaan di luar Indonesia yang ramai menggunakan blogger, vlogger, public figure yang fokus memanfaatkan media sosialnya untuk mempromosikan produk dan brand perusahaan. Buzzer akan sangat efektif dalam merangkul publik karena telah memiliki followers sebanyak ribuan bahkan jutaan tentu mendekati dan mempersuasi Sang Buzzer sendiri bukan hal yang murah karena proses menjadi seorang aktivis media sosial dan memiliki banyak pengikut bukan hal yang mudah. Namun, konsep buzzer/influencer sendiri masih dapat dilakukan tanpa banyak dana, karena sebenarnya konsep ini telah berjalan secara natural di seluruh perusahaan namun belum dikembangan secara maksimal. Lewat influencer yang secara langsung dimiliki oleh perusahaan bernama 'internal and external consumer'. Ya, karyawan sebagai konsumen internal dan publik sebagai konsumen eksternal.
Dua kelompok tersebut memiliki potensi tinggi untuk mempromosikan perusahaan karena mereka akan memberikan feedback yang lebih terasa alamiah dan tulus daripada buzzer dimana konsep membayar buzzer yang menggunakan public figure untuk berpromosi sudah banyak diketahui publik.

Perusahaan dapat menggerakkan tenaga sedikit lebih banyak untuk menawarkan engagement dan kedekatan seperti yang telah dilakukan banyak perusahaan berkembang di luar sana. Contoh, pada Instagram account NYX (sebuah brand makeup internasional) dan Sugar Bear Hair (sebuah brand multivitamin kesehatan rambut based in the USA) menggunakan proses consumer engagement. NYX melakukan re-posting dari hampir seluruh makeup artist amatir dan semi professional yang menggunakan produk-produk NYX pada wajahnya yang tentu dengan karakter makeup unik dan bold yang mewakili identitas NYX sebagai brand makeup yang memproduksi warna produk yang kaya dan sangat beragam serta jenis-jenis makeup tools yang terdiri dari banyak fungsi. NYX melakukan reposting dari akun para makeup artist atau konsumen biasa yang dengan inisiatifnya sendiri menggunakan produk NYX dan membuat testimonial akan produk yang ia gunakan bahkan turut menyertakan produk brand lainnya akn membuat hal ini terasa alamiah dan natural karena tidak terkesan NYX membayar seorang makeup artist terkenal yang melakukan foto makeup hanya menggunakan produk NYX saja. Begitu pula konsep sama yang dilakukan oleh Sugar Bear Hair, hanya saja mereka melakukan reposting dari para konsumen biasa yang telah mengkonsumsi produk multivitamin tersebut dan mempamerkan 
foto before after diri dan rambutnya yang sukses berkat konsumsi produk Sugar Bear Hair.

\section{Trend Masa Depan Humas dan Korporasi di Indonesia}

Menurut penulis, tren yang akan (dan harus) berkembang bagi Humas dan Korporasi di Indonesia adalah pemberlakuan engagement yang lebih erat dan terasa antar perusahaan dan publik lewat pemanfaatan digitalisasi media dan media sosial. Hal tersebut akan jauh lebih optimal berjalan apabila hampir seluruh korporasi membukan lowongan dan membentuk divisi khusus bagi 'Social Media Specialist Division' yang dapat masuk ke departemen Humas (atau mungkin Marketing Communication). Karyawan-karyawan muda yang cekatan dan peka melihat tren pada media sosial serta mampu mendeteksi kemampuan para social media activist dalam menggaet followers dan mengkomunikasikan brand pribadinya juga menjadi nilai plus selain kemampuannya dalam menulis tweet dalam 140 karakter yang mampu mewakili informasi, memanfaatkan blog, membuat vlog, melakukan optimalisasi mesin penelusuran dsb. Korporasi-korporasi yang berkembang juga harus percaya bahwa kekuatan media sosial akan membantu perusahaan untuk memperkenalkan identitas dengan tentunya diiringi oleh keunikan karakter produk yang juga mendukung brand awareness di mata publik, setelah mempercayai bahwa media sosial mampu memiliki kekuatan yang begitu besar, mereka juga harus telaten, komitmen dan bertanggung jawab pada apa yang telah dimulai, tidak meninggalkan media sosial begitu saja dapat menjadi kunci bagi publik untuk mengetahui bahwa media sosial tersebut sehat, berjalan, dan aktif, sebagai petanda bahwa perusahaan tersebut juga masih beroperasi, dapat dihubungi dengan mudah, serta terpantau kegiatannya oleh publik, terlepas dari mungkin jumlah followers yang belum banyak atau lama melakukan peningkatan. Selain itu, humas dan korporasi juga harus tetap membuka pikiran terhadap kemampuan event planning yang dilakukan Humas pada publik (serta banyak agenda kegiatan lainnya) bahwa hal ini akan berdampak banyak, dan agar publik masih dapat merasakan euphoria atau manfaat gelaran event yang sudah dilakukan dengan biaya mahal, perusahaan wajib melakukan aktivitas atau kegiatan pasca-event untuk membuat publik tetap terikat dengan kegiatan dan perusahaan tersebut. Hal-hal seperti ini memang harus dikoordinasikan antara karyawan Humas tradisional (analog) dan juga Humas Digital/Social Media Activist. Bahkan sebenarnya perusahaan dapat menggali pencarian bakat seseorang yang tengah meraih popularitasnya sebagai Buzzer guna menjadi brand ambassador bagi perusahaan. Apabila perusahaan peka dan ingin menghemat uang, perusahaan tidak perlu rutin membayar seorang Buzzer yang sudah terkenal agar mau terus menjadi influencer bagi perusahaan. Humas dapat membuat semacam duta yang justru diinisiasikan terlebih dahulu dari perusahaan dan dibentuk dari seorang pengguna media sosial yang misalnya memiliki minimal followers 1000 ke atas. Hal ini akan membuat banyak ketertarikan pengguna media sosial yang sudah memiliki basic banyak pengikut agar mereka semua berlomba-lomba menciptakan konten mengenai product \& brand sebuah perusahaan. 


\section{PENUTUP}

\section{Kesimpulan}

Penelitian ini mengemukakan kaitan Microblogging Twitter bagi Hubungan Masyarakat dalam sudut pandang industri, teknologi dan komunikasi. Penulis berpendapat bahwa pemanfaatan media sosial yang merupakan produk teknologi digital dapat bermanfaat bagi industri perusahaan guna menargetkan pengguna Twitter sebagai calon atau kandidat target market dari perusahaan. Praktisi Hubungan Masyarakat harus bekerjasama dengan ahli teknologi informasi atau social media expertise untuk menelaah kategorisasikategorisasi dari karakter konsumen atau target market yang dapat dikelompokkan berdasarkan karakter yang sama. Misalnya, perusahaan penerbit album musik K-Pop, harus bekerjasama dengan social media expertise atau ahli teknologi informasi untuk menarik data yang berisi pengelompokan sesuai karakter yang dibutuhkan yaitu pengguna Twitter yang berusia remaja sampai dewasa awal yang sering melakukan proses retweet dan melakukan like pada cuitan yang bernuansa budaya Korea ataupun pengguna yang memiliki karakter merupakan followers dari musisi K-Pop dan sebagainya. Hal ini kemudian akan berpengaruh pada kemudahan perusahaan untuk memantau apa yang sedang disenangi oleh remaja fans K-Pop dan memberikan kemudahan pula untuk melakukan following kepada para pengguna Twitter sekaligus penggemar KPop sehingga akan mudah untuk menjalankan program bisnis yang dapat disampaikan informasinya serta mengundang keikutsertaan bagi para penikmat K-Pop. Selain itu, industri yang sudah maju dan memiliki banyak followers atau pengikut di Twitter dapat melakukan mini survey lewat Twitter yang langsung ditanyakan kepada penggemar, dan dapat dengan mudah mendapatkan masukan, saran dan kritik membangun yang ditujukan langsung pada perusahaan dari pengguna yang seperti telah disebutkan di atas, bersifat one on one.

Optimalisasi Twitter dengan penggunaan yang smart merupakan penciptaan teknologi di perusahaan yang merupakan inovasi dalam memudahkan kinerja Hubungan Masyarakat. Holtz (1998, p.16-21) berkata bahwa komunikasi telah diubah secara mendalam dengan manfaat dari media online serta berpindah dari industri ekonomi menjadi ekonomi informasi, komunikasi telah berubah dari yang awalnya hirarkis (the broadcast paradigm) menjadi sebuah komunikasi yang berjaringan, sistemnya dapat dengan mudah terakses (the network paradigm). Ketika volume data yang massive telah menjadi sebuah hal yang available di dalam sebuah organisasi mengenai preferensi dan kesukaan konsumen, produk dan layanan pun kini dapat menjadi lebih customer-driven dibandingkan producerdriven. Penulis juga melihat bahwa dengan pemanfaatan Twitter, kini perusahaan akan menjadi lebih terinduksi ke tengah-tengah kehidupan masyarakat karena sifatnya yang disebut oleh Holtz (1998) sebagai komunikasi yang menarik setiap individu, pada satu waktu, ke dalam perusahaan.

\section{Saran}

Pada tulisan atau penelitian berikutnya, dapat memanfaatkan berbagai macam studi kasus berbagai perusahaan yang memanfaatkan Social Media Buzzer baik di Twitter, Facebook atau Instagram dalam mengukur efisiensi berniaga lewat kekuatan post dari para buzzer. 


\section{UCAPAN TERIMA KASIH}

Penulis mengucapkan terima kasih kepada kampus Pascasarjana Ilmu Komunikasi Universitas Indonesia serta kepada Dr. Irwansyah selaku dosen mata kuliah Perspektif Industri, Teknologi dan Komunikasi untuk dukungannya dalam keikutsertaan kegiatan penelitian ilmiah ini.

\section{DAFTAR PUSTAKA}

Ale, Felix. 2015. Journalism and Corporate Communications : A Nigerian Case Study. German : Grin Verlag

Bakan, J. (2004). The Corporation: The Pathological Pursuit of Profit and Power. Toronto: Viking Canada

Chami, R., Fullenkamp, R., Sharma, S. (2016). Trust As a Means of Improving Corporate Governance and Efficiency. International Monetary Fund Working Papers

Evans, A., Twomey, J., Talan, S., (2011). Twitter as a Public Relations Tool. Public Relations Journal, Vol.5 No. 1. Public Relations Society of America

Gregory, A. (2004). Scope and structure of public relations: A technology driven view. Public Relations Review, 30 (3), 245-254

Heibert, R.E. (2004). Commentary: New Technologies, Public Relations and Democracy. Public Relations Review, 31(1), 1-9

Holtz, H. (1998). The Consultant's Guide to Getting Business on the Internet:
How to Network for Clients and Business Opportunities. New York: John Wiley \& Sons Inc Information Resources Management Association (2018). Social Media Marketing: Breakthroughs in Research and Practice. USA: IGI Global

Java, A., Song, X., Finin, T. \& Tseng, B. (2007). Why we Twitter: Understanding microblogging usage and communities. Proceedings of the $9^{\text {th }}$ WebKDD 2007 workshop on Web mining and social network analysis (pp. 56-65). New York, NY: Association for Computing Machiner

Kirat, M. (2007). Promoting Online Media Relations: Public Relations Department's Use of Internet in the $U A E$. Public Relations Review, 33, 166-174

Lievrouw, Leah. 2011. Alternative and Activist New Media. United Kingdom: Polity Press Murthy, D. (2018). Twitter. United Kingdom: Polity Press

Morgan, C. (2016). Above The Noise: Creating Trust, Value \& Reputation Online Using Digital Public Relations. Motivational Press Inc.

Rezaei, S., Dana, L., Ramadani, V., (2017). Iranian Entrepreneurship : Deciphering the Entrepreneurial Ecosystem in Iran and In The Iranian Diaspora. Switzerland : Springer

Theaker, A. (2001). The Public Relations Handbook. London: Routledg 